NBER WORKING PAPER SERIES

\title{
WHO SHOULD SUPERVISE? THE STRUCTURE OF BANK SUPERVISION AND THE PERFORMANCE OF THE FINANCIAL SYSTEM
}

\author{
Barry Eichengreen \\ Nergiz Dincer \\ Working Paper 17401 \\ http://www.nber.org/papers/w17401 \\ NATIONAL BUREAU OF ECONOMIC RESEARCH \\ 1050 Massachusetts Avenue \\ Cambridge, MA 02138 \\ September 2011
}

The second author greatfully acknowledges financial support of TUBITAK (The Scientific and Technological Research Council of Turkey) under TUBITAK-BIDEP fellowship. The views presented here are those of the authors; and do not necessarily reflect the official position of the State Planning Organization or the National Bureau of Economic Research.

NBER working papers are circulated for discussion and comment purposes. They have not been peerreviewed or been subject to the review by the NBER Board of Directors that accompanies official NBER publications.

(C) 2011 by Barry Eichengreen and Nergiz Dincer. All rights reserved. Short sections of text, not to exceed two paragraphs, may be quoted without explicit permission provided that full credit, including (C) notice, is given to the source. 
Who Should Supervise? The Structure of Bank Supervision and the Performance of the Financial System

Barry Eichengreen and Nergiz Dincer

NBER Working Paper No. 17401

September 2011

JEL No. G0,G01,H1

\begin{abstract}
We assemble data on the structure of bank supervision, distinguishing supervision by the central bank from supervision by a nonbank governmental agency and independent from dependent governmental supervisors. Using observations for 140 countries from 1998 through 2010, we find that supervisory responsibility tends to be assigned to the central bank in low-income countries where that institution is one of few public-sector agencies with the requisite administrative capacity. It is more likely to be undertaken by a non-independent agency of the government in countries ranked high in terms of government efficiency and regulatory quality. We show that the choice of institutional arrangement makes a difference for outcomes. Countries with independent supervisors other than the central bank have fewer nonperforming loans as a share of GDP even after controlling for inflation, per capita income, and country and/or year fixed effects. Their banks are required to hold less capital against assets, presumably because they have less need to protect against loan losses. Savers in such countries enjoy higher deposit rates. There is some evidence, albeit more tentative, that countries with these arrangements are less prone to systemic banking crises.
\end{abstract}

\author{
Barry Eichengreen \\ Department of Economics \\ University of California, Berkeley \\ 549 Evans Hall 3880 \\ Berkeley, CA 94720-3880 \\ and NBER \\ eichengr@econ.Berkeley.edu \\ Nergiz Dincer \\ T.R. Prime Ministry State Planning Organization \\ Necatibey cad. No:108, Yucetepe \\ 06100, Ankara, TURKEY \\ nergiz.dincer@gmail.com
}




\section{Who Should Supervise? \\ The Structure of Bank Supervision and the Performance of the Financial System N. Nergiz Dincer and Barry Eichengreen ${ }^{1}$ August 2011}

In 1997-8 the British government transferred responsibility for supervising commercial banks from the Bank of England to a newly-created independent supervisory agency, the Financial Services Authority (FSA). In 2010-11 it then took steps to transfer that authority back, creating a Financial Policy Committee within the Bank and establishing a Prudential Regulatory Authority as a Bank of England subsidiary while refocusing the FSA on consumer protection (Ferran 2011).

This reversal reflected distinctive aspects of the UK's experience, notably the failure of supervisors to head off problems in a prominent building society, Northern Rock. ${ }^{2}$ It reflected their failure to prevent the first bank run in the United Kingdom in more than a century, an outcome widely if not unanimously attributed to imperfect coordination and inadequate information sharing between the FSA and the Bank of England. More generally, this vacillation was indicative of uncertainty about the appropriate locus of responsibility for bank supervision an uncertainty was by no means limited to the UK - and of a dearth of evidence about what works best. ${ }^{3}$

Before the crisis, arguments for assigning prudential supervision to an independent agency separate from the central bank has been gaining adherents. ${ }^{4}$ Removing supervision from the central bank, it was said, would avoid conflicts of interest between its price-stability mandate and concern for the stability of the financial system. ${ }^{5}$ The central bank would be less likely to follow inflationary monetary policies in order to paper over banking-system weaknesses inadequately addressed by its own prior supervision. Political pressure to accommodate banking-sector problems, which might distort the conduct of monetary policy, would be less. The drive to make central banks independent would be more palatable politically if the responsibilities of the institution were limited to targeting low and stable inflation. ${ }^{6}$ With this limited mandate, it would become easier to hold independent central banks politically accountable for their actions.

The supervisory competence of central banks, moreover, centered on commercial banks, whereas over time the line between bank and nonbank financial firms (between commercial banks and so-called "shadow banks," for example) was increasingly difficult to draw. As the case for consolidated supervision of these different classes of financial institutions became more compelling, the dilemma was whether to force the central bank out of its comfort zone, forcing it into oversight into nonbank institutions with which it had little familiarity, or to transfer

\footnotetext{
${ }^{1}$ State Planning Organization, Ankara and University of California, Berkeley.

2 Technically, a cooperative bank specializing in mortgage lending.

${ }^{3}$ There were other similar contemporaneous debates of whether and how much the central bank should be involved in prudential regulation, in South Korea for example.

${ }^{4}$ As we show more systematically below.

${ }^{5}$ See Gerlach, Giovannini, Tille and Viñals (2009) for a post-crisis reiteration of the point.

${ }^{6}$ Thus in the UK case the decision to hive off supervisory responsibilities from the Bank of England was part of the same decision making process that made the central bank independent.
} 
responsibility for supervision to a separate agency. Increasingly one heard arguments for the latter.

A worry with transferring supervisory authority to a governmental agency separate from the central bank was that the new supervisor would be subject to political influence. Hence the argument for making that consolidated supervisor independent: that statutory and budgetary independence would better insulate the supervisor from lobbying and rent seeking. It would allow the supervisor to go about its business without undue political influence. Statutory and budgetary independence would be politically palatable, moreover, because the range of responsibilities of the supervisor would be limited, making it easier to hold that independent authority accountable for its actions. ${ }^{7}$

The global financial crisis then turned these arguments on their head. In crises the central bank is provider of emergency liquidity to the banking system. ${ }^{8}$ As lender of last resort, the central bank must be involved in supervision and regulation of the banking and financial system. But it cannot be expected to provide emergency liquidity if it does not possess up-to-date information on the condition of the banks, and it is unlikely to possess such information is it is not intimately involved in their supervision. The central bank is the ultimate guarantor of financial stability, and it cannot make good on that guarantee in the absence of the kind of information that can only be obtained through hands-on supervision. ${ }^{9}$

Moreover, information on the condition of the banking and financial system of the sort that only a supervisor possesses is important for the conduct of monetary policy not just in crisis times (Ferguson 2001). ${ }^{10}$ Whether, for example, UK monetary policy would have been different in the period prior to the 2007 crisis had the Bank of England possessed supervisory authority is debatable, but it is question worth pondering.

Close coordination and information sharing between a self-standing supervisor and the central bank can in principle assure the monetary authority of access to similar information. But what is true in principle may not be true in practice. When supervision takes place outside the central bank, monetary policy makers will have less capacity to compel supervisors to share. Retaining information is one way that bureaucracies increase their leverage. Critics of this view (e.g. Goodhart 2000) observe that cooperation between central banks, other supervisors, and their respective treasuries/finance ministries has been ongoing for years and that a considerable amount of effort has been invested in making such cooperation work.

As with many things economic, then, there are arguments pointing both ways. And there is little systematic evidence on the effects of alternative arrangements. There may be an

\footnotetext{
${ }^{7}$ On this see for example Quintyn and Taylor (2003).

${ }^{8}$ An alternative would be for the independent supervisor to have a line of credit with the finance ministry or central bank so that it can undertake lender-of-last-resort interventions, but such arrangements have been rare in practice, presumably because the central bank is concerned about what such a facility would imply for its own ability to achieve its other objectives.

${ }^{9}$ A forceful statement of these arguments is DeGrauwe (2007).

${ }^{10}$ Peek, Rosengarten and Toottel (1999) provide evidence that supervisory authority is a source of information useful for forecasting.
} 
abundance of anecdote, but we know of little systematic analysis for a large cross section of countries relating the structure of bank supervision to financial-market outcomes.

We attempt to provide such an analysis in this paper. We assemble data on the structure of bank supervision, distinguishing supervision by the central bank from supervision by a nonbank governmental agency and independent from dependent governmental supervisors. We consider as many as 140 countries from 1998 through $2010 .^{11}$ We attempt to understand both the choice of supervisory arrangement and its effect on financial variables.

The results indicate that the ratio of nonperforming loans to GDP is lower in countries where supervision is delegated to a government agency with statutory and budgetary independence. In such countries banks are required to hold less capital relative to assets as a buffer against loan losses. There is also some evidence, admittedly more fragile, that systemic banking crises are less frequent. Strikingly, a number of these patterns are reversed for countries where supervision is the responsibility of the central bank.

\section{Data}

We start by asking whether or not supervisory responsibility rests principally with the central bank. Where responsibility is shared, this requires making a decision about who is the lead or principal supervisor. Where the supervisor is not the central bank, we then ask whether the supervisory agency in question is independent of the government. We ask first whether the supervisory agency has its own revenue sources and guaranteed budget or must rely on the parliament or government for its operating budget. We ask next whether the agency in question is part of another government agency like the ministry of finance or central bank, or whether it is independent of these other entities. We define the agency as independent if it satisfies both criteria.

In coding national arrangements, we examined central bank websites, which indicate whether or not the central bank is charged with such responsibilities. Where a central bank website or related sources indicate that supervisory responsibility lies with another government agency, we cross-checked the website of the agency in question. The resulting information was then further verified by checking the statutes in question and using independent descriptions on the website of the Bank for International Settlements and in Courtis (1999), Keay (2008), and Masciandero, Quintyn and Taylor (2008).

Thus we distinguish three cases: independent governmental agency, dependent governmental authority, and central bank. Trends are shown in Figure 1. It will be evident that supervision by independent agencies was relative rare as late as 1998 (when the UK made its high-profile shift). Following that there was a noticeable increase in the prevalence of this arrangement, which peaked in 2007. ${ }^{12}$ Evidently, there has been little overall movement

\footnotetext{
${ }^{11}$ There have been some similar efforts at categorization before (see e.g. Goodhart and Schoenmaker 1995, Goodhart, Hartmann, Llewellyn, Rojas-Suarez and Weisbrod 1998), but for much more limited sets of countries. More recently, Masciandero, Quintyn and Taylor (2008) construct measures of the independent of supervisors (distinguishing supervision by the central bank from supervision by another public agency) for 55 countries for a shorter period of time than considered here. We return to some of their findings below.

${ }^{12}$ Readers with keen eyesight and/or strong priors may be able to detect a logistic curve.
} 
subsequent to that. Clearly most of the increase in the prevalence of independent supervision has come at the expense of central banks.

Figure 1. Share of Independent Bank Supervisors and Central Bank Supervisors

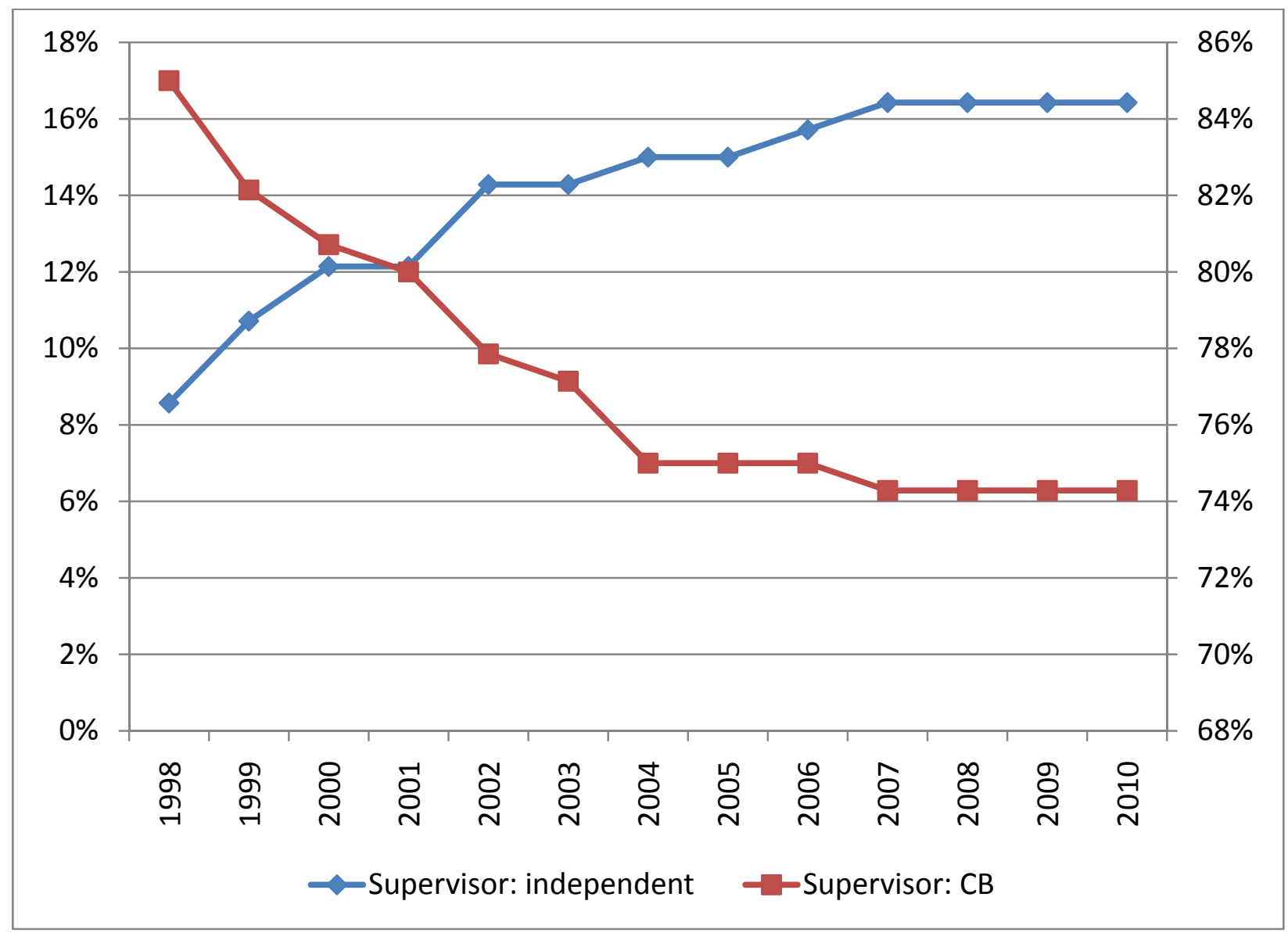

As explanatory variables we consider dummies for legal origin, indicators of political and institutional development, and financial and macroeconomic conditions. Dummy variables for the origin of the legal code are from La Porta, Lopez-de-Silanes, Shleifer and Vishny (1998). Political stability, rule of law, voice and accountability, government effectiveness and regulatory quality are from Kaufmann, Kraay and Mastruzzi (2010). The financial market indicators we consider are M2, credit by banking sector and nonperforming loans, all as shares of GDP, the ratio of bank capital to bank assets, and the interest rate on deposits. Macroeconomic indicators are log real GDP per capita (in international prices) and CPI inflation, from World Development Indicators. 


\section{Regression Analysis}

We first explore the determinants of the structure of bank supervision. While this is interesting in its own right, it is also useful for identifying potential instrumental variables for institutional arrangements to be employed when we consider their impact on financial structure and stability.

As noted, we code the structure of bank supervision as taking on different values when it is assigned to an independent authority, a dependent governmental authority, and the central bank. Per capita GDP (our proxy for economic development) enters positively in Table 1 for both independent and dependent governmental supervisors; in less developed, low-income countries, supervisory responsibility is more likely to be assigned to the central bank, in other words. This is consistent with the observation that the central bank is one of few public-sector agencies with the capacity to act as an effective supervisor and that the obstacles to sharing information and coordinating responses across agencies may be especially great in a poorcountry setting. Countries with recent histories of inflation are also more likely to delegate supervision to an independent governmental agency, perhaps reflecting the limited success with which their central banks have dealt with conflicts.

An independent supervisor is also less likely to be observed in countries with an English legal tradition and more likely in countries with a tradition of German law. German law registers positively for both the independent and dependent governmental supervisor categories; by implication, significant supervisory responsibility for the central bank is less likely in such cases. The UK-law result is striking, given that the UK itself had an independent supervisory authority separate from the central bank in this period (although this is no longer the case). So is the German-law result, given that the Bundesbank is involved in supervision as auditor of bank operations and organizer of routine and ad hoc prudential discussions with financial institutions. German and Scandinavian legal traditions have much in common, however, and the Scandinavian countries have been in the vanguard of those creating independent supervisory agencies outside the central bank.

Supervision is more likely to be undertaken by a non-independent agency in countries coded as having efficient governments and high-quality regulation. Where government agencies are high-quality, efficient regulators, it can be argued, there will be less pressure to outsource supervisory functions to the central bank or another independent agency. Supervision is more likely to be assigned to an independent agency where public-sector accountability is high, accountability being a standard quid pro quo for independence; for arguments to this effect see inter alia Plosser (2010). Masciandero, Quintyn and Taylor (2008) report similar findings. Finally, supervision is more likely to be assigned to the central bank in countries rated highly in terms of rule of law and political stability; these correlations are harder to interpret. 
Table 1. Determinants of Structure of Bank Supervision, Multinomial Logit

\begin{tabular}{|c|c|c|c|c|c|c|}
\hline \multicolumn{7}{|c|}{ Independent supervisor } \\
\hline & Coef. & Std. Err. & $Z$ & $\mathrm{P}>|\mathrm{z}|$ & \multicolumn{2}{|c|}{ [95\% Conf. Interval] } \\
\hline Constant & -22.11 & 2.65 & -8.34 & 0.00 & -27.30 & -16.91 \\
\hline GDP per capita & 2.10 & 0.28 & 7.55 & 0.00 & 1.55 & 2.64 \\
\hline Past Inflation & 1.92 & 0.90 & 2.15 & 0.03 & 0.17 & 3.68 \\
\hline Rule of law & -1.10 & 0.45 & -2.45 & 0.01 & -1.98 & -0.22 \\
\hline Political stability & -1.32 & 0.24 & -5.45 & 0.00 & -1.79 & -0.84 \\
\hline Accountability & 2.27 & 0.35 & 6.42 & 0.00 & 1.57 & 2.96 \\
\hline Gov. effectiveness & -0.32 & 0.47 & -0.70 & 0.49 & -1.24 & 0.59 \\
\hline Regulatory quality & 0.65 & 0.38 & 1.71 & 0.09 & -0.09 & 1.39 \\
\hline German law & 0.47 & 0.22 & 2.10 & 0.04 & 0.03 & 0.90 \\
\hline UK law & -1.43 & 0.27 & -5.34 & 0.00 & -1.96 & -0.91 \\
\hline \multicolumn{7}{|c|}{ Other government agency } \\
\hline & Coef. & Std. Err. & $Z$ & $P>|z|$ & \multicolumn{2}{|c|}{ [95\% Conf. Interval] } \\
\hline Constant & -8.74 & 2.03 & -4.30 & 0.00 & -12.73 & -4.75 \\
\hline GDP per capita & 0.68 & 0.23 & 3.01 & 0.00 & 0.24 & 1.12 \\
\hline Past Inflation & -4.49 & 2.25 & -2.00 & 0.05 & -8.90 & -0.08 \\
\hline Rule of law & -3.75 & 0.55 & -6.79 & 0.00 & -4.83 & -2.67 \\
\hline Political stability & -0.33 & 0.26 & -1.29 & 0.20 & -0.84 & 0.17 \\
\hline Accountability & -0.28 & 0.26 & -1.08 & 0.28 & -0.78 & 0.22 \\
\hline Gov. effectiveness & 2.11 & 0.59 & 3.59 & 0.00 & 0.96 & 3.26 \\
\hline Regulatory quality & 2.10 & 0.45 & 4.64 & 0.00 & 1.21 & 2.98 \\
\hline German law & 0.74 & 0.26 & 2.86 & 0.00 & 0.23 & 1.24 \\
\hline UK law & -16.80 & 443.78 & -0.04 & 0.97 & -886.60 & 852.99 \\
\hline Number of obs & $=$ & \multicolumn{2}{|c|}{1443} & & & \\
\hline LR chi2(18) & $=$ & \multicolumn{2}{|c|}{659.35} & & & \\
\hline Prob > chi2 & $=$ & \multicolumn{2}{|c|}{0.00} & & & \\
\hline Pseudo R2 & $=$ & \multicolumn{2}{|c|}{0.34} & & & \\
\hline Log likelihood & $=$ & \multicolumn{2}{|c|}{-651.69} & & & \\
\hline
\end{tabular}

Given that legal origin, government efficiency, accountability and regulatory quality are predetermined or slow to change - and that they are not readily affected by current financial conditions - we use them as instruments in second-stage regressions relating the structure of supervision to financial outcomes. We show those second-stage regressions in Tables 2-4. The dependent variables are credit by the banking sector and M2 as shares of GDP (as measures of financial development), nonperforming loans as a percent of GDP (as a measure of the performance of lending), the capital-to-asset ratio (as a measure of bank capitalization), and the deposit rate (as a measure of returns to savers). Each row shows a regression for a different dependent variable. Lagged inflation and GDP per capita as controls and year fixed effects are included throughout.

Table 2 suggests that countries with independent supervisors have fewer nonperforming loans, other things equal. Their banks are able to hold less capital as a share of assets, presumably as a result. Deposit rates are higher in such countries, indicating better returns to 
savers, perhaps indicating less financial repression and less banking-sector intervention by the government in pursuit of other objectives. Bank credit and M2 as shares of GDP are not significantly affected by the structure of bank supervision, by and large.

Table 2. Impact of an Independent Bank Supervisor on Banking Sector Development (GMM with period fixed effects)

\begin{tabular}{lcccccc}
\hline Dependent Variables & Constant & IS & PCPI & GDPPC & J-stat & \#obs \\
\hline Credit by Banking Sector (\% of GDP) & -8.88 & 13.04 & 14.30 & 0.99 & 2.68 & 1227 \\
& $(-0.90)$ & $(1.68)$ & $(0.80)$ & $(0.94)$ & & \\
Capital to Asset Ratio (\% of GDP) & -0.07 & $-0.10^{* * *}$ & $0.69^{* * *}$ & $0.02^{* *}$ & 30.70 & 720 \\
& $(-0.98)$ & $(-4.21)$ & $(4.06)$ & $(2.21)$ & & \\
Deposit Rate & $0.32^{* * *}$ & $0.13^{* * *}$ & $0.28^{* *}$ & $-0.03^{* * *}$ & 19.74 & 1150 \\
& $(5.50)$ & $(3.71)$ & $(2.56)$ & $(-5.02)$ & & \\
Nonperforming Loans (\% of GDP) & $0.19^{* * *}$ & $-0.12^{* * *}$ & $0.26^{* *}$ & $-0.01^{*}$ & 10.54 & 741 \\
& $(3.07)$ & $(-4.51)$ & $(2.33)$ & $(-1.67)$ & & \\
M2 (\% of GDP) & 0.06 & 0.06 & $-4.82^{* * *}$ & 0.09 & 4.11 & 1195 \\
& $(0.09)$ & $(0.12)$ & $(-4.81)$ & $(1.24)$ & & \\
\hline
\end{tabular}

* denotes significance at $10 \%$, ** denotes significance at $5 \%$ and $* * *$ denotes significance at $1 \%$. †t-statistics in parentheses. IS is a dummy variable which takes value 1 when the supervisor is independent, and 0 otherwise.

Note: Dependent variables are in rows. Instruments are rule of law, political stability, accountability, government efficiency and regulatory quality and legal origin dummies.

Table 3 contrasts supervision by the central bank. Evidently nonperforming loans are higher and banks are required to hold more capital as a share of assets when the central bank is the principal supervisor. Deposit rates are lower. These patterns are the obverse of what we find for independent supervisors. Again there is no evidence of an impact on M2 or credit by the banking sector.

For completeness, Table 4 shows the impact of having a non-independent government agency responsible for supervision. These effects can of course be inferred from Tables 2 and 3, but displaying them adds clarity. We find that nonperforming loans are higher than under alternative arrangements and that banks are correspondingly required to hold more capital. Deposit rates are lower than under alternative institutional arrangements. M2 as a per cent of GDP is significantly lower than under other institutional arrangements, as if countries with politically dependent supervisors end up with less developed financial systems. 
Table 3. Impact of Central Bank Supervision on Banking Sector Development (GMM with period fixed effects)

\begin{tabular}{lcccccc}
\hline Dependent Variables & Constant & CBS & PCPI & GDPPC & J-stat & \#obs \\
\hline Credit by Banking Sector (\% of GDP) & -4.86 & -6.52 & 6.75 & 1.36 & 2.84 & 1227 \\
& $(-0.65)$ & $(-1.38)$ & $(0.51)$ & $(1.24)$ & & \\
Capital to Asset Ratio (\% of GDP) & -0.20 & $0.08^{* * *}$ & $0.95^{* * *}$ & $0.02^{*}$ & 3.66 & 720 \\
& $(-1.61)$ & $(2.90)$ & $(3.89)$ & $(1.92)$ & & \\
Deposit Rate & $0.48^{* * *}$ & $-0.11^{* * *}$ & 0.04 & $-0.04^{* * *}$ & 18.63 & 1150 \\
& $(5.83)$ & $(-4.50)$ & $(0.33)$ & $(-5.49)$ & & \\
Nonperforming Loans (\% of GDP) & $0.28^{* * *}$ & $0.05^{* * *}$ & $0.22^{* *}$ & $-0.02^{* * *}$ & 40.32 & 741 \\
& $(4.46)$ & $(2.63)$ & $(2.41)$ & $(-5.00)$ & & \\
M2 (\% of GDP) & -0.57 & 0.18 & $-4.16^{* * *}$ & $0.14^{* *}$ & 4.46 & 1195 \\
& $(-0.72)$ & $(0.78)$ & $(-3.51)$ & $(2.31)$ & & \\
\hline
\end{tabular}

$*$ denotes significance at $10 \%,{ }^{* *}$ denotes significance at $5 \%$ and $* * *$ denotes significance at $1 \%$.

†t-statistics in parentheses. CBS is a dummy variable which takes value 1 when the supervisor is central bank, and 0 otherwise.

Note: Dependent variables are in rows. Instruments are rule of law, political stability, accountability, government efficiency and regulatory quality and legal origin dummies.

Table 4. Impact of an Non-independent Government Supervisor on Banking Sector Development (GMM with period fixed effects)

\begin{tabular}{lcccccc}
\hline Dependent Variables & Constant & GS & PCPI & GDPPC & J-stat & \#obs \\
\hline Credit by Banking Sector (\% of GDP) & -19.45 & 13.96 & 11.16 & 2.36 & 3.16 & 1211 \\
& $(-1.39)$ & $(0.67)$ & $(0.73)$ & $(1.47)$ & & \\
Capital to Asset Ratio (\% of GDP) & $0.23^{* * *}$ & $0.07^{* * *}$ & 0.12 & $-0.02^{* * *}$ & 9.74 & 709 \\
& $(3.97)$ & $(3.17)$ & $(0.69)$ & $(-3.07)$ & & \\
Deposit Rate & $0.31^{* * *}$ & $0.20^{* * *}$ & 0.02 & $-0.03^{* * *}$ & 13.29 & 1130 \\
& $(4.66)$ & $(3.78)$ & $(0.09)$ & $(-4.36)$ & & \\
Nonperforming Loans (\% of GDP) & $0.41^{* * *}$ & $0.38^{* *}$ & 0.09 & $-0.04^{* * *}$ & 33.11 & 730 \\
& $(9.29)$ & $(2.57)$ & $(0.87)$ & $(-8.80)$ & & \\
M2 (\% of GDP) & -0.70 & $-0.75^{* *}$ & $-2.61^{* *}$ & $0.17^{* * *}$ & 4.99 & 1174 \\
& $(-1.51)$ & $(-2.17)$ & $(-2.05)$ & $(3.73)$ & & \\
\hline
\end{tabular}

$*$ denotes significance at $10 \%$, ** denotes significance at $5 \%$ and $* * *$ denotes significance at $1 \%$.

$\dagger t$-statistics in parentheses. GS is a dummy variable which takes value 1 when the supervisor is a nonindependent institution, and 0 otherwise.

Note: Dependent variables are in rows. Instruments are rule of law, political stability, accountability, government efficiency and regulatory quality and legal origin dummies.

We can explore further the validity of our interpretation that independent supervision makes for better loan performance and a safer financial system by considering the impact of the structure of supervision on the incidence of banking crises. The ratio of nonperforming loans as 
a share of GDP is of course only one factor making for banking crises, albeit an important one. We would therefore expect somewhat weaker results than for loans and capital.

We use the World Bank-IMF indicator of systemic banking crises from Leuven and Valencia (2010). We estimate linear probability models with the binary banking-crisis indicator as the dependent variable, since we are not concerned to fit predicted values on the basis of the equation. ${ }^{13}$ The other independent variables are the same as above.

For the entire period, the coefficients on the supervision indicators are uniformly insignificant. But the 2007-10 global financial crisis was an equal opportunity event; it affected countries with all kinds of supervisory arrangements. When we therefore limit the sample to 1998-2006 we find that countries with independent supervisors were less prone to banking crises. The coefficient on the indicator for an independent supervisor is negative and differs significantly from zero at the ten per cent confidence level. This is consistent with our interpretation of the other estimates above. We should emphasize that this result is more fragile than those for other dependent variables; it is sensitive to sample period and estimator. And we do not find a significant correlation, either positive or negative, between supervision by the central bank and the incidence of banking crises.

The data thus seem to suggest that there are advantages of independent supervision. When supervision is done by an independent agency other than the central bank, nonperforming loans are lower, enabling banks to hold less capital relative to assets. There is also some evidence of a more tentative nature that banking crises are less frequent when supervision is by an independent agency other than the central bank. The same effects are not evident when the regulatory agency lacks statutory and budgetary independence. In addition, depositors enjoy higher returns when supervision not done by the central bank; this finding seems to apply to independent and non-independent supervisors alike.

\section{Alternative Methodology}

An alternative approach to analyzing these questions is propensity score matching (PSM). This involves matching the observations for the treatment group with those for a control group with similar characteristics. In the present context, countries with an independent bank supervisor are the treatment group. They comprise 257 our 1,807 country-year observations. The remaining observations then constitute the control group.

Conditional on a vector of covariates $\mathrm{X}$, we assume that the expected value of our financial market development indicators would be the same for treatment and control-group observations that are paired together. Subject to this assumption, we can take the control observations as twins of the treated observations had the latter not received treatment. Thus, the difference between the treated and control observations will be an estimate of the effect of employing an independent bank supervisor. The vector of covariates $\mathrm{X}$ should include variables that are determinants of both financial market conditions and the likelihood of employing an independent supervisor.

\footnotetext{
${ }^{13}$ Were we concerned with predicted values a logit or probit model would be appropriate.
} 
The vector $\mathrm{X}$ consists of country characteristics such as the macroeconomic variables, legal origin dummies and political variables considered above. Matching based on X must still confront the problem of multidimensionality. Rosenbaum and Rubin (1983) suggest matching on the probability of employing an independent bank supervisor conditional on the vector X. When two observations have a similar propensity score, they are paired according to either nearest neighbor matching or kernel matching. In the nearest neighbor approach, the individual from the comparison group is chosen as a matching partner for a treated individual that is closest in terms of the propensity score. Kernel matching (KM) is a nonparametric matching estimator that uses weighted averages of nearly all individuals in the control group to construct the counterfactual outcome. All treated units are matched with a weighted average of all controls, with weights inversely proportional to the distance between the propensity scores of the treated and control groups. Because all control units contribute to the weights, lower variance is achieved.

As a first stage of estimating a PSM model, we again estimate a probit model explaining the likelihood of a country employing an independent bank supervisor, following the specification used in Table 1. This model differs from that in Table 1 in that only two values of the dependent variable (independent supervisor and other) are distinguished, since this is necessary in order to implement the standard PSM approach.

We then use two different propensity matching methods for the purpose of robustness: nearest neighbor matching (Table 5) and kernel matching (Table 6). Country-year fixed effects are included throughout.

Table 5. Propensity Score Matching using Nearest Neighbor Matching

\begin{tabular}{|c|c|c|c|c|c|c|c|}
\hline Variable & & Sample & Treated & Controls & Difference & S.E. & T-stat \\
\hline M2 (\% of & & Unmatched & 59.53 & 57.32 & 2.21 & 5.46 & 0.40 \\
\hline & & ATT & 59.53 & 74.12 & -14.59 & 7.75 & -1.88 \\
\hline Credit by & $\%$ of GDP) & Unmatched & 91.58 & 64.47 & 27.12 & 7.81 & 3.47 \\
\hline & & ATT & 91.58 & 86.43 & 5.16 & 11.31 & 0.46 \\
\hline Nonperfol & (\% of GDP) & Unmatched & 3.39 & 8.86 & -5.47 & 0.91 & -6.04 \\
\hline & & ATT & 3.39 & 4.91 & -1.52 & 0.70 & -2.16 \\
\hline Deposit R & & Unmatched & 8.38 & 6.86 & 1.52 & 0.81 & 1.87 \\
\hline & & ATT & 8.38 & 4.85 & 3.53 & 1.38 & 2.56 \\
\hline Capital to & latio & Unmatched & 7.97 & 10.26 & -2.29 & 0.48 & -4.75 \\
\hline & & ATT & 7.97 & 9.48 & -1.51 & 0.48 & -3.13 \\
\hline Untreated & 392 & & & & & & \\
\hline Treated & 91 & & & & & & \\
\hline Total & 483 & & & & & & \\
\hline
\end{tabular}

Note: Nearest neighborhood matching is used where the independent variables are regulatory quality, GDP per capita, legal origin dummies, past inflation and fixed effects. 
Table 6. Propensity Score Matching using Kernel Matching

\begin{tabular}{|c|c|c|c|c|c|c|c|}
\hline \multicolumn{2}{|l|}{ Variable } & Sample & Treated & $\begin{array}{c}\text { Control } \\
\mathrm{s}\end{array}$ & Difference & S.E. & T-stat \\
\hline \multirow{2}{*}{\multicolumn{2}{|c|}{ M2 (\% of GDP) }} & Unmatched & 59.53 & 57.32 & 2.21 & 5.46 & 0.40 \\
\hline & & ATT & 60.61 & 71.49 & -10.89 & 5.95 & -1.83 \\
\hline \multirow{2}{*}{\multicolumn{2}{|c|}{ Credit by Banks (\% of GDP) }} & Unmatched & 91.58 & 64.47 & 27.12 & 7.81 & 3.47 \\
\hline & & ATT & 92.92 & 80.28 & 12.64 & 9.04 & 1.40 \\
\hline \multirow{2}{*}{\multicolumn{2}{|c|}{ Nonperforming L. (\% of GDP) }} & Unmatched & 3.39 & 8.86 & -5.47 & 0.91 & -6.04 \\
\hline & & ATT & 2.94 & 5.37 & -2.42 & 0.77 & -3.14 \\
\hline \multirow{2}{*}{\multicolumn{2}{|c|}{ Deposit Rate }} & Unmatched & 8.38 & 6.86 & 1.52 & 0.81 & 1.87 \\
\hline & & ATT & 6.78 & 5.18 & 1.60 & 0.89 & 1.79 \\
\hline \multirow{2}{*}{\multicolumn{2}{|c|}{ Capital to Asset Ratio }} & Unmatched & 7.97 & 10.26 & -2.29 & 0.48 & -4.75 \\
\hline & & ATT & 7.99 & 9.63 & -1.64 & 0.47 & -3.48 \\
\hline Untreated & 392 & & & & & & \\
\hline Treated & 91 & & & & & & \\
\hline Total & 483 & & & & & & \\
\hline
\end{tabular}

Note: Kernel matching is used where the independent variables are regulatory quality, GDP per capita, legal origin dummies, past inflation and fixed effects.

The results are consistent with what we found above. Nonperforming loans and capital-to-asset ratios are lower in countries with independent supervisors, while deposit rates are higher. The coefficient on the deposit rate slips below statistical significance at the 95 per cent confidence level in Table 6 where we use kernel matching, but only marginally. We take this as confirmation of our previous findings.

\section{Conclusion}

We have related the structure of bank supervision to economic and financial outcomes, distinguishing countries in which supervision is undertaken principally by the central bank, by another legally and fiscally independent agency of government, and by a non-independent government agency. Recent events have raised questions about the efficacy of prevailing arrangements. Even where the question of who should supervise was seemingly settled, those recent events would appear to have thrown it open again.

We find that supervisory responsibility tends to be assigned to the central bank in lowincome countries where the central bank is one of few public-sector agencies with the capacity to act as an effective supervisor and where the obstacles to sharing information and coordinating responses across agencies are especially great. It is more likely to be undertaken by a nonindependent agency of the government in countries ranked high in terms of government efficiency and regulatory quality. Supervision is often assigned to an independent agency in countries where governmental accountability is high, given that accountability is a standard quid pro quo for independence. 
The choice of institutional arrangement makes a difference for outcomes. Countries with independent supervisors other than the central bank have fewer nonperforming loans as a share of GDP even after controlling for inflation, per capita income, and country and/or year fixed effects. Their banks are required to hold less capital against assets, presumably because they have less need to protect against loan losses. They enjoy higher deposit rates. And there is some evidence, albeit more tentative, that they are less prone to systemic banking crises.

On balance, these results suggest that the global financial crisis may have given independent supervision a bum rap. 


\section{References}

Courtis, Neil (1999), How Countries Supervise Their Banks, Insurers and Securities Markets, London: Central Banking Publications.

DeGrauwe, Paul (2007), “There is More to Central Banking than Inflation Targeting,” VoxEU (14 November).

Donze, Steve (2006), "Bank Supervisor Independence and the Health of Banking Systems: Evidence from OECD Economies,” unpublished manuscript, London School of Economics (May).

Ferguson, Roger (2000), “Alternative Approaches to Prudential Supervision and Regulation,” Journal of Financial Services Research 17, pp.297-303.

Ferran, Eilis (2011), “The Breakup of the Financial Services Authority,” Oxford Journal of Legal Studies 1, pp.1-26.

Gerlach, Stefan, Alberto Giovannini, Cédric Tille and José Viñals (2009), “Are the Golden Days of Banking Over? The Crisis and the Challenges,” Geneva Reports on the World Economy 10.

Goodhart, Charles (2000), “The Organisational Structure of Bank Supervision,” Financial Stability Board Occasional Paper no.1, Basel: Bank for International Settlements.

Goodhart, Charles, Phillip Hartmann, David Llewellyn, Liliana Rojas-Suarez and Steven Weisbrod (1998), Financial Regulation: Why, How and Where? London: Routledge.

Goodhart, Charles and Dirk Schoenmaker (1995), "Institutional Separation between Supervisory and Monetary Agencies,” in Charles Goodhart (ed.), The Central Bank and the Financial System, London: Macmillan.

Kaufmann, Daniel, Aart Kraay and Massimo Mastruzzi (2010), Worldwide Governance Indicators, Washington, D.C.: World Bank.

Keay, Justin (2008), How Countries Supervise Their Banks, Insurers and Securities Markets, London: Central Banking Publications.

LaPorta, Rafael, Florencio Lopez-de-Silanes, Andre Shleifer and Robert Vishney (1998), “Law and Finance,” Journal of Political Economy 106, pp.1133-1155.

Leuven, Luc and Fabian Valencia (2010), "Systemic Banking Crises: A New Data Set,” unpublished manuscript: IMF.

Masciandero, Donato, Marc Quintyn and Michael Taylor (2008), “Inside and Outside the Central Bank: Independence and Accountability in Financial Supervision: Trends and Determinants,” European Journal of Political Economy 24, pp.833-848.

Peek, Joe, Eric Rosengarten and G. Toottel (1999), “Is Bank Supervision Central to Central Banking?” Quarterly Journal of Economics 114, pp.629-653.

Plosser, Charles (2010), “The Federal Reserve System: Balancing Independence and Accountability,” speech to the World Affairs Council of Philadelphia (17 February). 
Quintyn, Marc and Michael Taylor (2003), "Regulatory and Supervisory Independence and Financial Stability,” CES-Ifo Economic Studies 49, pp.259-294.

Rosenbaum, P. R., and Rubin, D. B., (1983), "The Central Role of the Propensity Score in Observational Studies for Causal Effects," Biometrika 70, pp.41-55. 